\title{
Strength Characteristics of Concrete Using Paper Sludge Ash and Foundry Sand
}

\author{
Anil Kumar ${ }^{1}$, Akshatha Shetty ${ }^{1}$ \\ ${ }^{1}$ Assistant Professor \\ Department of Civil Engineering, NMAMIT, Nitte, Karkala, Karnataka, India
}

\begin{abstract}
The Rapid Construction activities has increased in the demand for concrete, which leads to overuse of natural resource in the manufacture of cement. Hence, conservation of natural resources is necessary. Among the wastes generated by the various industries it is presumed that 10\%-15\% of wastes are hazardous and increasing at the rate of 2\%-5\% per year, resulting in environmental pollution and effect to living beings.

The present work is focused on the use of wastes such as paper sludge (from Paper Mill Industry) which can be utilized as alternative construction material, so that it would be one of the consistent ways of disposal. The study also incorporates the use of foundry sand as a partial replacement for sand. Experiments were performed to understand the strength parameters such as compressive and tensile strength of Paper Sludge Ash $5 \%, 10 \%$, and 15\%) as a partial replacement of cement and Foundry Sand (20\%, 40\% and 60\%) as a partial replacement of fine aggregate. From the study it can be observed that replacement of cement with $40 \%$ foundry sand $8.12 \%$ increase in compressive strength was obtained. Mix with $40 \%$ replacement of foundry sand and $5 \%$ replacement of Paper Sludge Ash gave the maximum Flexural Strength compared to other mix.
\end{abstract}

Keywords: Paper Sludge Ash (PSA), Foundry Sand (FS), Compressive Strength, Tensile Strength, Flextural Strength.

\section{INTRODUCTION}

In this rapid moving era of construction industry plays a very important role in of infrastructure development of any Country. The concrete is one of the main components in the construction activity whose manufacturing process consists of ingredients like cement, aggregates, water and admixtures. Concrete is used predominantly as construction material as it can full-fill all the important requirement such as strength, durability, impermeability, fire resistance and abrasion resistance. Due to rapid growth in industrialization large amount of wastes are been generated and the disposal of such waste has been a problem. Hence the reuse of this waste material can be enhanced. Therefore, the wastes which are disposed from industries and agricultural sectors could be used as an alternative building material, so that the conservation of natural resources and disposal of harmful wastes can be reduced. Due the increase in demand for the concrete, the demand for the raw materials such as such as river sand and coarse aggregate also increased.

The present work is focused on the usage of the Paper Sludge Ash (PSA) used in concrete as a partial substitute for cement and foundry sand (FS) as a partial substitute for river sand. Both the materials used here are the waste generated in industries. If such materials are found suitable in concrete making both reduction in cost of construction material as well as safe disposal of waste materials can be achieved.

\section{LiTERATURE REVIEW}

\subsection{General}

Several experimental investigations were carried out by various researchers on concrete wherein cement and fine aggregates are partly replaced by Paper Sludge Ash and Foundry Sand and the Strength parameters such as compressive strength, tensile strength and flexural strength were obtained. An overview of research work carried out by various researchers in the field of Waste Foundry Sand and paper sludge ash are been summarized. 
Paper sludge and paper sludge ash both are potentially useful products in manufacturing of cement and also the blended Cement (Dunster, 2007) .Valeria et al. (2011) also stated that Paper Sludge Ash (PSA) can be used as supplementary cementatious material. Experiments results of work carried by Rajgor and Pitroda (2013) reveled that when the cement is replaced by paper industry waste by $10 \%-70 \%$ by its weight a strength increase was achieved by $30 \%$ compared to test results are compared with the conventional concrete .Similarly the Naik et al. (1994) Investigated the performance of concrete consisting discarded foundry sand. A mix is proportioned to replace natural sand by $25 \%$ and $35 \%$ of clean/used foundry sand. The experimental results based on compressive strength At 28 days the concrete containing used foundry sand gave20\%-30\% lower value when compared to control mix. But concrete containing clean/new foundry sand gave almost the same compressive strength as that of the control mix. Siddique et al. (2008) achieved strength of $30 \% \mathrm{~s}$ when fine aggregate was replaced by $30 \%$ foundry sand.

\section{Materials USED}

\subsection{Paper Sludge Ash}

Paper Sludge ash (Fig.3.1) is the waste product obtained in the manufacture of paper from the paper mill industry. It imposes a major economic and environmental crisis in Paper and board industry as it's a waste product and imposes difficulty in dumping. Paper sludge is currently in use as an alternative fuel. In the present study paper sludge ash are collected from Mangalore Paper mills Ltd., Kenya , Talapady, Mangalore.physical and chemical properties of Paper sludge ash in given in Table 1.

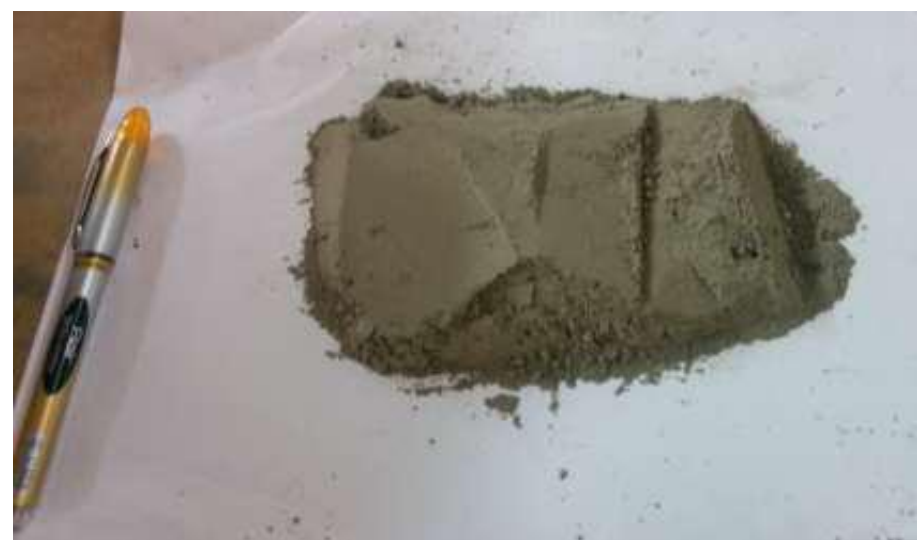

Figure3.1. Paper Sludge Ash

Table1. Physical and Chemical Properties of Paper Sludge Ash

\begin{tabular}{|l|l|l|l|l|}
\hline S1.No. & \multicolumn{2}{|c|}{ Physical Properties } & \multicolumn{2}{c|}{ Chemical Properties } \\
\hline 1. & Colour & Ash grey Silicon Dioxide & Silicon Dioxide & $59.47 \%$ \\
\hline 2. & Specific gravity & 2.61 & Calcium Oxide & $8.69 \%$ \\
\hline 3. & Appearance & $\begin{array}{l}\text { Powder Alumina and } \\
\text { Ferric Oxide }\end{array}$ & $\begin{array}{l}\text { Alumina and Ferric } \\
\text { Oxide }\end{array}$ & $10.45 \%$ \\
\hline 4. & Fineness (90 micron sieve) & $9 \%$ & Magnesium Oxide & $3.13 \%$ \\
\hline
\end{tabular}

\subsection{Foundry Sand}

Foundry sand is a by-product of both ferrous and non-ferrous metal casting industry. This sand is usually used in moulding process in foundry as it contain high thermal conductivity. The physical and chemical properties depend on the casting process involved in foundries. For the present work Foundry sand was obtained from Lamina Foundry Ltd. Nitte, Karkala Taluk, Udupi District, and Karnataka, India. 5. See Fig 3.2 and the properties of foundry sand are tabulated in Table 2.

Table2. Physical Properties of Foundry sand

\begin{tabular}{|l|l|l|}
\hline Sl. No. & Characteristics & Obtained values \\
\hline 1. & Colour & Black \\
\hline 2. & Specific gravity & 2.36 \\
\hline 3. & Water absorption & $15.789 \%$ \\
\hline 4. & Grain fineness index & 56.55 \\
\hline
\end{tabular}




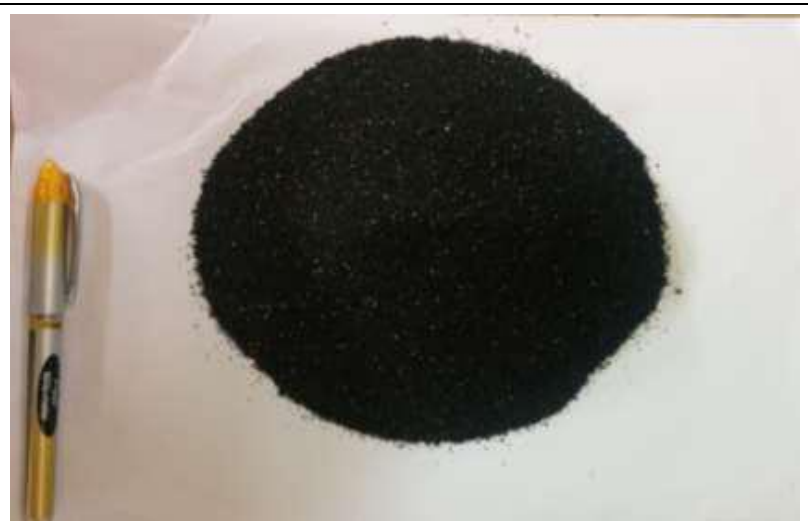

Figure3.2. Foundry Sand

\subsection{Cement}

The OPC 43 grade cement (Vasavadatta Birla Shakti) is used throughout the work. The cement used is fresh and without lumps and satisfied the requirement of IS: 8112-1989.

\subsection{Fine Aggregate}

The test were conducted as per IS 2386 (part 3): 1963, the fine aggregate Used in the present Work was $4.75 \mathrm{~mm}$ down size. Various test results are shown in Table 3.

Table3. Physical Properties of Fine Aggregate

\begin{tabular}{|l|l|l|}
\hline Sl.no. & Characteristics & Obtained values \\
\hline $\mathbf{1 .}$ & Specific gravity & 2.63 \\
\hline $\mathbf{2 .}$ & Water absorption & $2.88 \%$ \\
\hline $\mathbf{3 .}$ & Fineness modulus & 3.32 \\
\hline $\mathbf{4 .}$ & Grading zone & Zone III \\
\hline
\end{tabular}

\subsection{Coarse Aggregate}

The tests were performed as per IS 2386 (part 3):1963, the coarse aggregated used are of size $20 \mathrm{~mm}$ and down size. The physical properties of the coarse aggregate are shown in Table 4.

Table4. Physical Properties of Coarse Aggregate

\begin{tabular}{|l|l|l|}
\hline Sl.no. & Characteristics & Obtained values \\
\hline 1. & Type of aggregate & Crushed angular \\
\hline $\mathbf{2 .}$ & Specific gravity & 2.71 \\
\hline $\mathbf{3 .}$ & Water absorption & $0.6 \%$ \\
\hline 4. & Fineness modulus & 3.91 \\
\hline
\end{tabular}

\subsection{Methodology}

Mix Design was done as per IS: 10262-2009. The details on the mix proportion for the conventional concrete are tabulated Table 5.

Table5. Mix proportion

\begin{tabular}{|l|l|l|l|l|}
\hline Grade & Cement $\left(\mathrm{Kg} / \mathrm{m}^{3}\right)$ & Fine Aggregate $\left(\mathrm{Kg} / \mathrm{m}^{3}\right)$ & Coarse Aggregate $\left(\mathrm{Kg} / \mathrm{m}^{3}\right)$ & Water $\left(\right.$ litre $\left./ \mathrm{m}^{3}\right)$ \\
\hline M25 & 1 & 1.94 & 3.15 & 0.43 \\
\hline
\end{tabular}

Further the studies were performed by the replacement of cement by paper sludge ash in a proportion of $5 \%, 10 \%$ and $15 \%\left(\mathrm{PSA}_{1}, \mathrm{PSA}_{2}\right.$ and $\mathrm{PSA}_{3}$ ) and fine aggregate is replaced by foundry sand by $20 \%$, $40 \%$ and $60 \%\left(\mathrm{FS}_{1}, \mathrm{FS}_{2}\right.$ and $\left.\mathrm{FS}_{3}\right)$. The samples were kept in water for curing for 7days, 14days and 28days and test for determination of compressive strength split and Flexural Strength of concrete was performed.

\section{EXPERIMENTAL RESULTS}

The strength characteristics of concrete using paper sludge ash and foundry sand was compared with the conventional concrete based on the experimental values. 


\subsection{Compressive Strength}

The development of strength was assessed by maturity testing, an effective way of assessing the strength of concrete at specified period in days. In the present work strength of concrete were evaluated as per IS516-1959 for different replacement level. See Fig 1. The compression strength value is tabulated in Table 6 and Fig 2 and Fig. 3

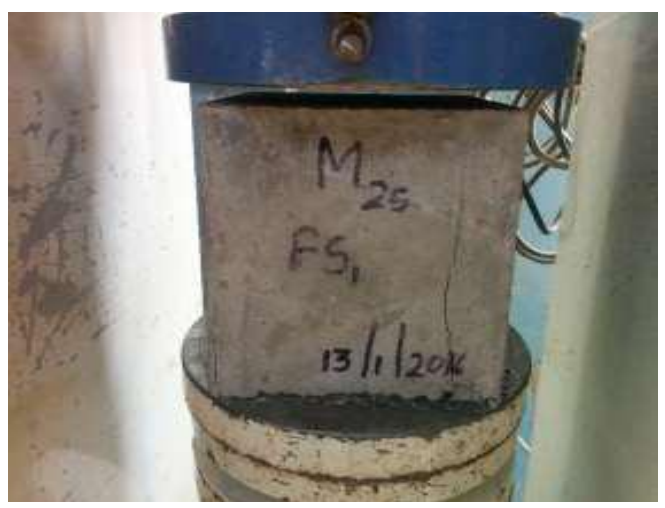

Figure1. Cracked Sample after compression test placed in UTM machine

Table6. Compressive Strength of Different Mix

\begin{tabular}{|l|l|l|l|}
\hline \multirow{2}{*}{ Mix Designation } & \multicolumn{4}{|l|}{ Avg. Compressive Strength of specimen in N/mm ${ }^{2}$ at curing period in days } \\
\cline { 2 - 4 } & 7 days & 14 days & 28 days \\
\hline CC (0\%) & $\mathbf{2 8 . 1 4}$ & $\mathbf{3 0 . 4 6}$ & $\mathbf{3 3 . 1 5}$ \\
\hline FS1 (20\%) & $\mathbf{2 6 . 6 2}$ & $\mathbf{2 9 . 7 0}$ & $\mathbf{3 3 . 4 4}$ \\
\hline FS2 (40\%) & $\mathbf{2 7 . 6 5}$ & $\mathbf{3 2 . 9 1}$ & $\mathbf{3 6 . 1 2}$ \\
\hline FS3 (60\%) & $\mathbf{2 4 . 1 2}$ & $\mathbf{2 5 . 1 4}$ & $\mathbf{2 6 . 9 2}$ \\
\hline PSA1 (5\%) & $\mathbf{2 6 . 8 9}$ & $\mathbf{2 8 . 8 2}$ & $\mathbf{3 2 . 8 0}$ \\
\hline PSA2(10\%) & $\mathbf{2 3 . 4 1}$ & $\mathbf{2 6 . 5 0}$ & $\mathbf{2 9 . 1 3}$ \\
\hline PSA3(15\%) & $\mathbf{2 2 . 5 8}$ & $\mathbf{2 3 . 2 3}$ & $\mathbf{2 3 . 2 0}$ \\
\hline BM1(FS2\&PSA1) & $\mathbf{2 4 . 8 6}$ & $\mathbf{2 8 . 4 0}$ & $\mathbf{3 2 . 1 0}$ \\
\hline
\end{tabular}
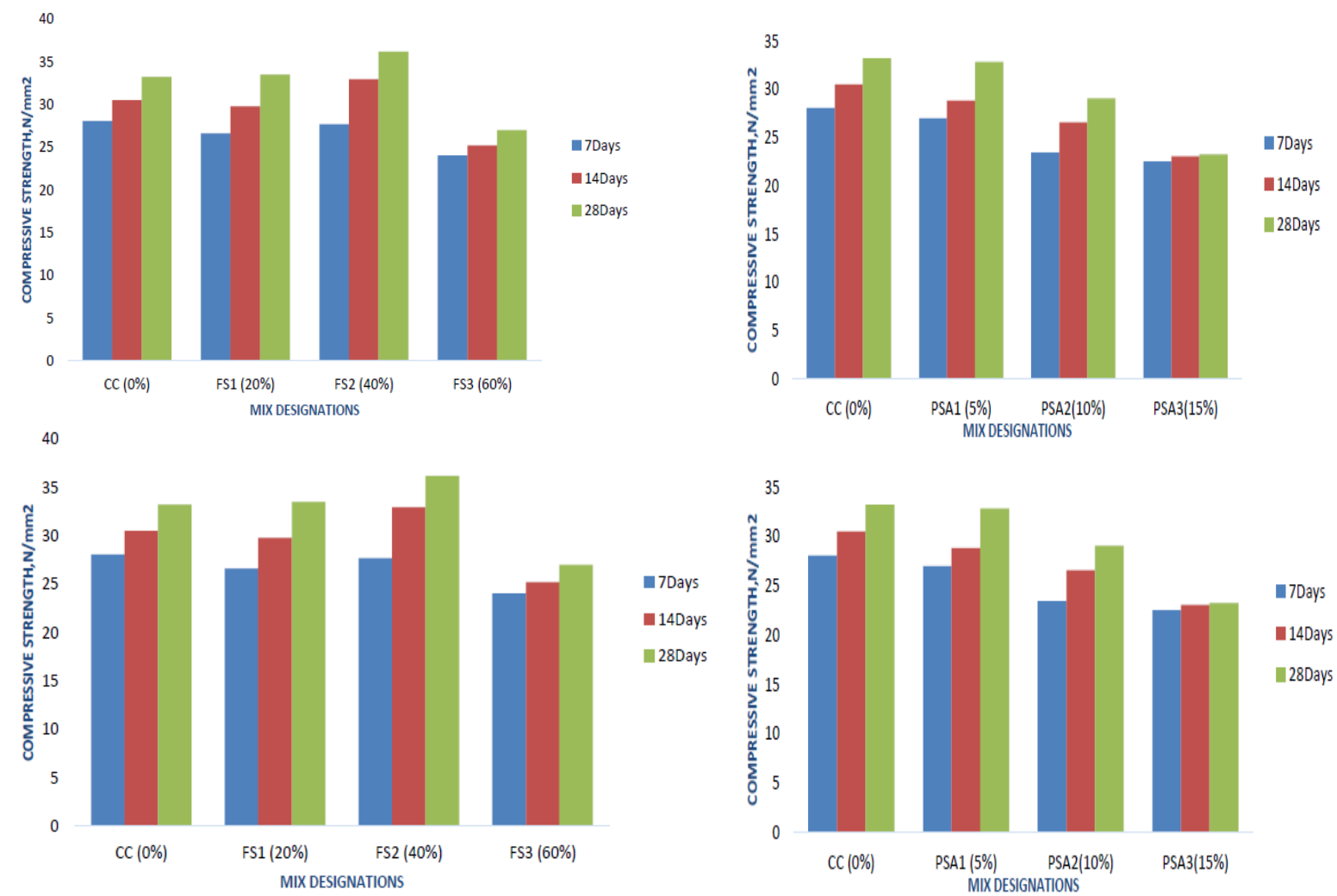

Figure2. Compressive Strength for Different Mixes with variation of Foundry Sand

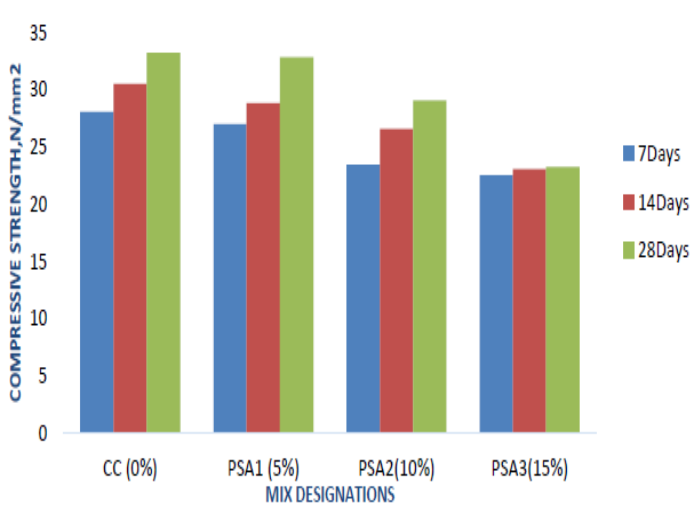

Figure3. Compressive Strength for Different Mixes with variation of Paper Sludge Ash. 


\subsection{Split Tensile Strength}

The split tensile test was conducted to determine the tensile strength of concrete. The tests were carried for different replacement level of cement as per IS5816-1999. The strength of 14 mixes for 7, 14 and 28 days is shown in Table 7 and these results were graphically represented in figure 4 and 5.

Table7. Split Tensile Strength of Different Mix

\begin{tabular}{|l|l|l|l|}
\hline \multirow{2}{*}{ Mix Designation } & \multicolumn{3}{|l|}{ Avg. Split Tensile Strength of specimen in N/mm ${ }^{2}$ at curing period in days } \\
\cline { 2 - 4 } & 7 days & 14 days & 28 days \\
\hline CC (0\%) & 2.10 & 2.98 & 3.67 \\
\hline FS1 (20\%) & 2.20 & 3.15 & 3.78 \\
\hline FS2 (40\%) & 3.26 & 3.94 & 4.16 \\
\hline FS3 (60\%) & 2.62 & 3.36 & 3.26 \\
\hline PSA1 (5\%) & 2.83 & 3.53 & 3.98 \\
\hline PSA2(10\%) & 2.24 & 2.62 & 3.01 \\
\hline PSA3(15\%) & 2.16 & 2.54 & 2.83 \\
\hline BM1(FS2\&PSA1) & 2.98 & 3.89 & 4.20 \\
\hline
\end{tabular}
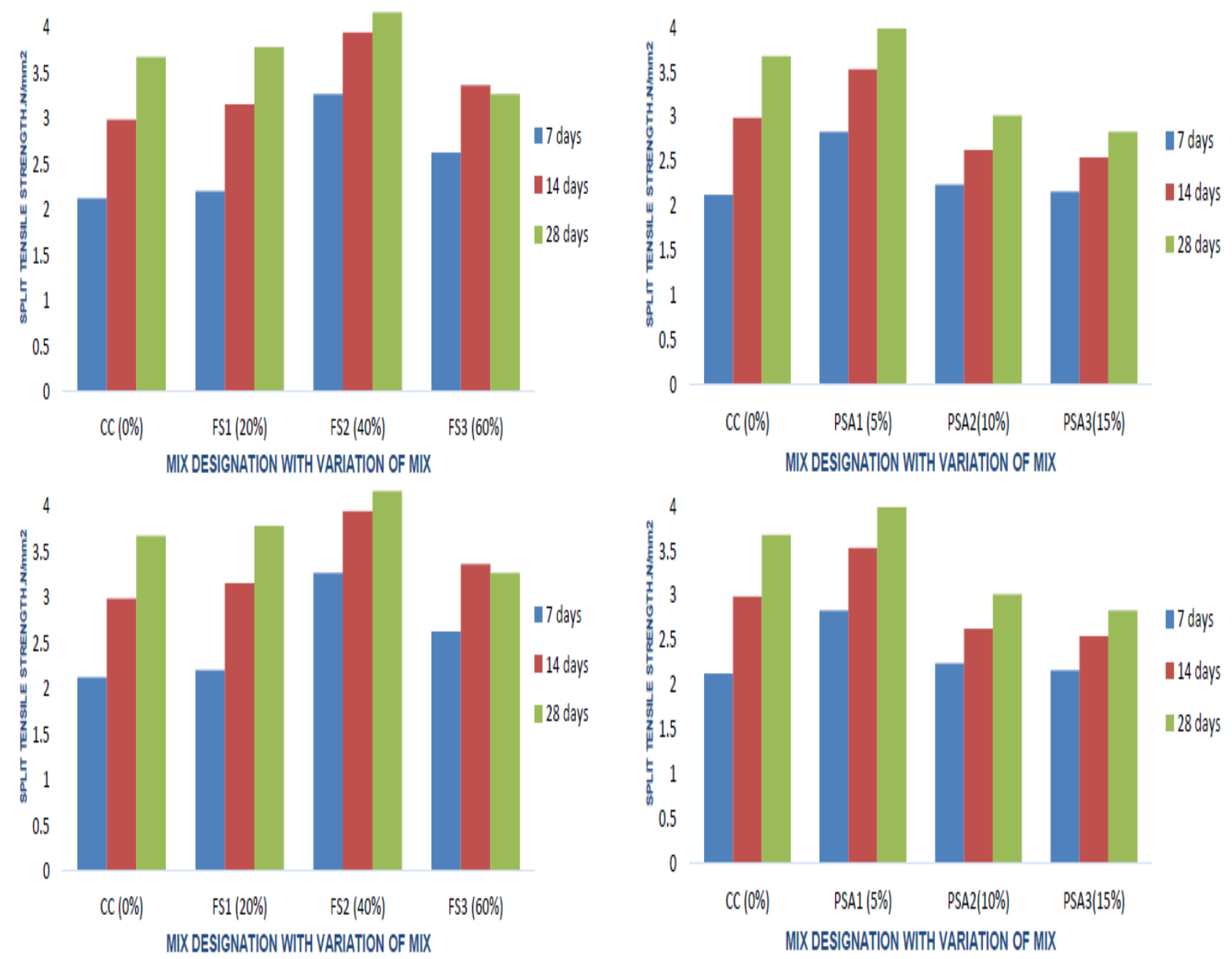

Figure4. Split Tensile Strength for Different Mixes with variation of Foundry Sand.

Figure5. Split Tensile Strength for Different Mixes with variation of Paper Sludge Ash.

\subsection{Flexural Strength}

The flexural strength is one among the direct methods through which tensile strength of concrete can be determined. The tests are carried for different cement replacement levels by paper sludge ash $(20 \%$, $40 \%$ and $60 \%$ ) and fine aggregate by foundry sand (5\%,10\%and 15\%) for curing period of 7, 14, 28 days. The optimum mix obtained for both replacements is then casted and strength is determined for 7 , 14 and 28 days. The strength of 8 mixes was shown in table 8 and these results were graphically represented in figure 6 and figure 7. 
Table8. Flexural Strength of Different Mix

\begin{tabular}{|l|l|l|l|}
\hline \multirow{2}{*}{ Mix Designation } & \multicolumn{3}{|l|}{ Avg. Split Tensile Strength of specimen in N/mm ${ }^{2}$ at curing period in days } \\
\cline { 2 - 4 } & 7 days & 14 days & 28 days \\
\hline CC (0\%) & 3.98 & 4.15 & 4.30 \\
\hline FS1 (20\%) & 4.12 & 4.36 & 4.54 \\
\hline FS2 (40\%) & 4.36 & 4.50 & 4.81 \\
\hline FS3 (60\%) & 4.24 & 4.38 & 4.66 \\
\hline PSA1 (5\%) & 3.84 & 4.22 & 4.38 \\
\hline PSA2(10\%) & 3.66 & 4.20 & 4.16 \\
\hline PSA3(15\%) & 3.24 & 3.98 & 4.12 \\
\hline BM1(FS2\&PSA1) & 4.18 & 4.26 & 4.45 \\
\hline
\end{tabular}

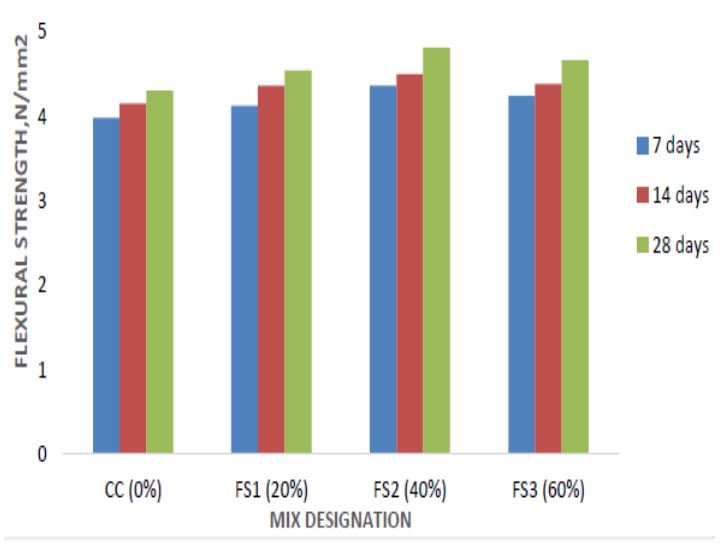

Figure6. Flexural Strength for Different Mixes with variation of Foundry Sand

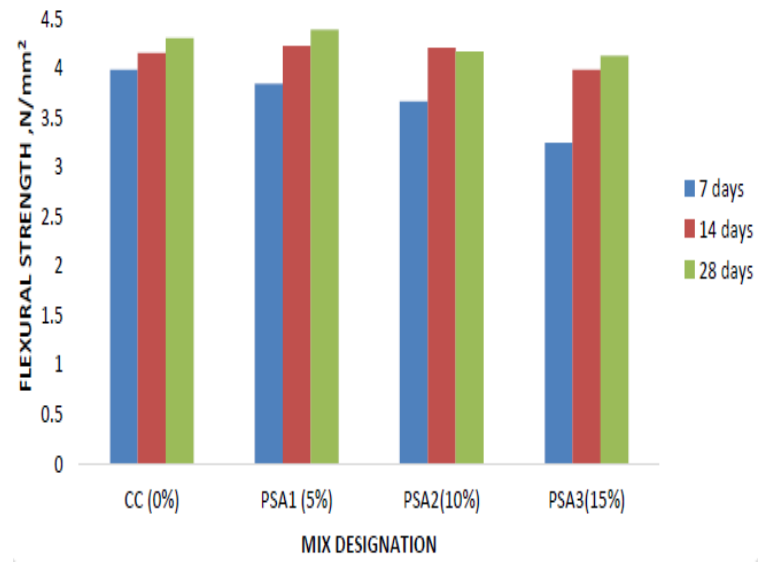

Figure7. Flexural Strength for Different Mixes with variation of Foundry Sand.

\section{Conclusion}

From the tests results of Compressive Strength Test, Split Tensile Strength Test and Flexural Strength the following conclusions are been listed;

Based on the compressive strength of specimen with different replacement level these conclusions are made

$>$ For the grade of concrete considered for the study, FS2 i.e. the ratio of 60:40 of Sand, Foundry Sand has proved to be having optimum ratio which gives maximum Compressive strength.

$>$ Similarly for the concrete PSA1 the ratio 95:5 of cement, proved to have maximum compressive strength.

$>$ At the replacement level of $40 \%$ foundry sand 28days strength was $8.16 \%$ greater than of conventional concrete mix.

From the experimental test results on Split Tensile Strength it is concluded that,

$>$ For the grade of concrete M25 considered for the study, Mix with 40\% replacement of foundry sand and 5\% replacement of Paper Sludge Ash is the optimum level at which Split Tensile Strength is Maximum.

$>$ Mix with $60 \%$ replacement of foundry sand and $15 \%$ replacement of Paper Sludge Ash gives the least Split Tensile Strength compared to other mix

From the experimental values of test on Flexural Strength it is concluded that,

$>$ For the grade of concrete M25 considered for the study, Mix with 40\% replacement of foundry sand and 5\% replacement of Paper Sludge Ash is the optimum level at which Flexural Strength is Maximum.

$>$ ii. Mix with 60\% replacement of foundry sand and 15\% replacement of Paper Sludge Ash gives the least Flexural Strength compared to other mix

The compressive, tensile and flexural strength results obtained for the casted sample whose mix contains optimum replacement values of paper sludge ash and foundry sand is found to give good result when compared to conventional mix. 


\section{ACKNOWLEDGMENT}

The authors are very thankful to Ms. Devika Rani, M. Tech student and Dept. of civil Engineering, NMAMIT, Nitte for their support to carry out this research work.

\section{REFERENCES}

[1] Andrew M Duster, "Characterization of Mineral Waste Resource and Processing TechnologiesIntegrated Waste Management For the Production of Construction Material”, 2007,pp 67-69.

[2] R. Balamurugan,R Karthickraja, "An Experimental Investigation of Partial Replacement of Cement by Industrial Waste" (Hypo Sludge) ISSN : 2248-9622, Vol. 4, Issue 4, April 2014, pp.430-435

[3] Foundry Industry Recycling Starts Today, "Foundry Sand Facts for Civil Engineering",2004,pp 80.

[4] Mamta B. Rajgor and Jayeshkumar Pitroda, "A Study on Paper Industry Waste:Opportunity for Development of Low Cost Concrete in Indian Contest", IJSR 2013 pp. 90-92.Rafat Siddique, Geert De. Schutter and Albert Noumowe, "Effect of Used Foundry Sand on the Mechanical Properties of Concrete", Construction of Building Materials 2008 pp. 976-980.

[5] Shetty M.S, Concrete Technology Theory and Practice, 7th edition S Chand Publication,India 2013.

[6] Tarun R. Naik, Viral M. Patel, Dhaval M. Patel and Mathew P. Tharaniyil, "Utilization of Used Foundry Sand in Concrete", Journal of Material in Civil Engineering. 1994 pp 254-263.

[7] Valeria Corinaldesi,Gabriele Fava ,Maria Letizia Ruello,"Paper Mill Ash as Supplementary Cementitious Material”, 2011,vol.23,pp 772-776.

\section{IS Codes of Practices}

[1] IS: 10262-2009 Concrete mix proportioning-Guidelines (First Revision), Bureau of Indian Standards, New Delhi.

[2] IS: 12269-1987 (Second Revision) [Reaffirmed in 1999], Specifications for Ordinary Portland Cement 53 grade, Bureau of Indian Standards, New Delhi.

[3] IS: 2386 (part III) 1963, Methods of test for aggregates for concrete- part 3: specific gravity, density, voids, absorption and bulking, Bureau of Indian Standards, New Delhi.

[4] IS: 383-1970 specification for coarse and fine aggregate from natural source for concrete.

[5] IS: 456-2000 Code of Practice for plain and reinforced cement concrete, (fourth revision) [Reaffirmed in 2002], Bureau of Indian Standards, New Delhi.

[6] IS: 5816-1999 (First Revision) splitting tensile strength of concrete - method of test, Bureau of Indian Standards, New Delhi.

[7] IS: 516-1959 [Reaffirmed 1999], Indian Standard for Strength of Concrete, Bureau of Indian Standards, New Delhi.8. IS: 8112-1989 [Reaffirmed 2005], OPC 43 grade. 